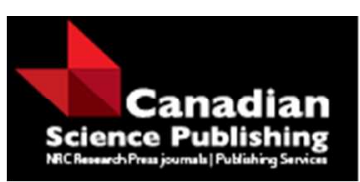

Canadian Journal of Forest Research Revue canadienne de recherche forestière

\title{
Natural root grafting in Picea mariana to cope with spruce budworm outbreaks
}

\begin{tabular}{|c|c|}
\hline Journal: & Canadian Journal of Forest Research \\
\hline Manuscript ID & cjfr-2016-0121.R1 \\
\hline Manuscript Type: & Article \\
\hline Date Submitted by the Author: & 17-May-2016 \\
\hline Complete List of Authors: & $\begin{array}{l}\text { Salomón, Roberto; Technical University of Madrid (UPM), Forest Genetics } \\
\text { and Ecophysiology Research Group } \\
\text { Tarroux, Emilie; Universite du Quevec en Abitibi-Temiscamingue, Institut } \\
\text { de Recherche sur les Forets } \\
\text { Desrochers, Annie; Universite du Quevec en Abitibi-Temiscamingue, } \\
\text { Institut de Recherche sur les Forets }\end{array}$ \\
\hline Keyword: & $\begin{array}{l}\text { black spruce }(<\mathrm{i}>\text { Picea mariana }</ \mathrm{i}>\text { ), insect defoliation, } \\
\text { dendrochronology, root graft, tree growth }\end{array}$ \\
\hline
\end{tabular}

\section{SCHOLARONE ${ }^{m}$ \\ Manuscripts}


1 Natural root grafting in Picea mariana to cope with spruce budworm outbreaks

2 Roberto L. Salomón ${ }^{1, *}$, Emilie Tarroux ${ }^{2}$, Annie DesRochers $^{2}$

$3 \quad{ }^{1}$ Forest Genetics and Ecophysiology Research Group, E.T.S. Forestry Engineering, Technical

4 University of Madrid (UPM), Ciudad Universitaria s/n 28040 Madrid, Spain

$5 \quad{ }^{2}$ Forest Research Institute, University of Quebec in Abitibi-Témiscamingue, 341 rue Principale

6 Nord, J9T 2L8 Amos, QC, Canada

7 * Corresponding author email: roberto.salomon@upm.es;

8 Phone: +34913367113

9 Fax: +34913572293

10 e-mail addresses of co-authors: Emilie.Tarroux@uqat.ca; Annie.Desrochers@uqat.ca; 


\section{Abstract}

13 Spruce budworm (Choristoneura fumiferana Clem.) outbreaks cause extensive mortality and growth

14 reductions throughout boreal forests in eastern North America. As tree vulnerability to defoliation

15 remains partially unexplained by tree and stand attributes, we hypothesized that root grafting might

16 attenuate the negative impact of severe defoliation in tree growth. Two experimental sites in the

17 Abitibi-Témiscamingue region dominated by black spruce (Picea mariana Mill.) were harvested and

18 hydraulically excavated to study tree growth in 36 trees in relation to root grafting and the last

19 outbreak using dendroecological methods. Root grafts reduced the negative effects of defoliation by

20 maintaining stable growth in connected trees during epidemic periods. Among dominant trees,

21 growth releases immediately after the outbreak were uniquely observed in grafted trees. Among

22 suppressed trees, grafted trees tended to grow more than non-grafted trees when defoliation severity

23 was the highest. Carbohydrate transfers through root grafts and enhanced efficiency to acquire

24 resources may explain the better performance of grafted trees under scenarios of limited carbon

25 supply. This study reinforces the growing body of literature that suggests root grafting as a

26 cooperative strategy to withstand severe disturbances and highlights the key role of root grafting in

27 stand dynamics to cope with periodic outbreaks.

\section{Keywords}

black spruce (Picea mariana); insect defoliation; dendrochronology; root graft; tree growth 


\section{Résumé}

33 Les épidémies de tordeuse des bourgeons de l'épinette (Choristoneura fumiferana Clem.) sont la 34 cause d'importantes réductions de croissance et de mortalité dans la forêt boréale de l'est de 35 l'Amérique du nord. Comme la vulnérabilité des arbres à la défoliation reste en partie inexpliquée 36 par les caractéristiques des arbres et des peuplements, nous avons posé l'hypothèse que le greffage 37 racinaire pouvait atténuer l'impact négatif de défoliations sévères sur la croissance des arbres. Deux 38 sites expérimentaux dominés par l'épinette noire (Picea mariana Mill.) ont été récoltés et excavés 39 hydrauliquement dans la région de 1'Abitibi-Témiscamingue afin d'étudier la croissance de 36 arbres en lien avec les greffes racinaires et la dernière épidémie de tordeuse par des méthodes dendroécologiques. Les greffes racinaires ont réduit l'effet négatif de la défoliation en maintenant une croissance plus ou moins stable des arbres greffés durant la période épidémique. Parmi les arbres dominants, la reprise de croissance suite à l'épidémie n'a été observée que pour les arbres greffés.

44 Chez les arbres supprimés, les arbres greffés tendaient à avoir une meilleure croissance que les arbres non greffés quand la sévérité de l'épidémie était à son maximum. Les transferts de sucres par les greffes racinaires et l'amélioration de l'efficacité d'acquisition des ressources pourraient expliquer la meilleure performance des arbres greffés dans des conditions d'approvisionnement en carbone limitées. Cette étude renforce la théorie qui suggère le greffage racinaire comme une stratégie de coopération entre les arbres pour résister aux perturbations sévères et met en lumière le rôle des greffes dans la dynamique des peuplements pour faire face aux épidémies.

\section{Mots-clé}

52 Épinette noire (Picea mariana); défoliation par les insectes; dendrochronologie; greffe racinaire; 53 croissance des arbres. 


\section{Introduction}

55 Spruce budworm (Choristoneura fumiferana Clem.) is the most damaging insect in boreal forests in 56 eastern North America (Morin et al. 2007). Insect outbreaks have a periodicity of 30-40 years

57 (Boulanger and Arseneault 2004, Boulanger et al. 2012) and cause extensive mortality, e.g., the latest 58 spruce budworm outbreak destroyed up to 238 million $\mathrm{m}^{3}$ of softwood in Quebec (Boulet et al. 1996). Larval feeding on foliage can cause tree growth reductions above $40 \%$ (Krause and Morin 1999, Pothier et al. 2005), and eventually tree death. Canopy gaps are progressively filled by growth releases of surviving trees, and they trigger recruitment and post-outbreak colonization (Morin 1994). Therefore, spruce budworm outbreaks are widely recognized as main drivers of forest dynamics in eastern North America (Morin et al. 1993, 2007, Morin 1994, Bouchard et al. 2007, Boulanger et al. 2012, Fierravanti et al. 2015).

The impact of spruce budworm defoliation on tree growth and mortality depends on several factors such as forest composition (Campbell et al. 2008, Colford-Gilks et al. 2012), site characteristics (MacKinnon and MacLean 2004), tree size (Bergeron et al. 1995), and tree age (Taylor and MacLean 2009). Tree vulnerability to outbreaks is crucial to predict forest dynamics and timber yield in boreal forests (Pothier et al. 2005, Bouchard et al. 2007, Morin et al. 2007), yet knowledge on tree vulnerability is limited in comparison to our understanding of tree susceptibility to budworm outbreaks (Pothier and Mailly 2006, Campbell et al. 2008). Variability in tree growth and mortality following budworm defoliation remains largely unexplained; e.g., stand characteristics accounted for $40 \%$ of the variance in growth reduction in balsam fir (Bergeron et al. 1995, Campbell et al. 2008), and $47 \%$ of the total deviation in tree mortality in spruce and fir trees (Colford-Gilks et al. 2012). Similarly, the coefficient of determination between ring-width index and defoliation intensity was below 0.4 and 0.2 in fir and spruce trees, respectively (Pothier et al. 2005, 2012), suggesting a relatively weak relationship between defoliation and tree growth, especially for the latter species 
78 (Pothier et al. 2012). These observations point to overlooked factors that might influence tree

79 performance to withstand budworm defoliation and could help to explain why some trees succumb to 80 outbreaks whilst others survive.

81 Root grafting is a widespread phenomenon observed in many species, about 200 according to 82 Graham and Bormann (1966). Although it migh occur much more extensively, given that it has received very little attention due to the difficulties to survey belowground tree attributes (Lev-Yadun 2011). Root connections could be beneficial under scenarios of limited carbon supply following outbreaks as greater acquisition of resources and shared carbohydrate pools within physiologically integrated individuals (see Stone and Stone, 1975; Fraser et al., 2005, 2006; and references therein) could attenuate the negative impact of defoliation in tree growth and mortality. Root grafting is gaining attention as an adaptive strategy to face disturbances and environmental hazards as cooperative behaviour could limit tree mortality and hinder establishment of new species (Eis 1972 , Tarroux and DesRochers 2011). Nevertheless, despite the potential role of root grafting to cope with outbreaks, and more widely, in stand dynamics in boreal forests in eastern North America, there is no literature assessing the relationship between budworm outbreaks and root grafting. In this study, we test the hypothesis of root grafting as a mechanism to survive budworm defoliation. We evaluated differences in stem growth between grafted and non-grafted trees following a spruce budworm outbreak. Dominant and suppressed trees were independently compared to avoid any related-effect of tree dominance (Eis 1972, Baret and DesRochers 2011). Additionally, we assessed a potential temporal correlation between defoliation intensity and formation of root grafts. We excavated two sites dominated by black spruce (Picea mariana Mill.) that were severely defoliated by the last spruce budworm outbreak that affected the Abitibi-Témiscamingue region (Morin et al. 1993). We predicted that the negative effect of budworm outbreak on tree growth would be lessened 101 in grafted trees in comparison to non-grafted trees, and that suppressed trees would benefit to a 
102 greater extent as they would be supported by connected dominant trees.

\section{Materials and methods}

\section{Study site and field work}

105 The study was performed at two sites dominated by black spruce naturally regenerated and located in

106 the western balsam fir-paper birch (Abies balsamea-Betula papyrifera) bioclimatic domain

107 (Grondin et al. 1996), near Amos city (Abitibi-Témiscaminge region, Quebec, Canada) (48³4' N

108 latitude, $78^{\circ} 07^{\prime} \mathrm{W}$ longitude). Mean annual precipitation during last 30 years was $918 \mathrm{~mm}(670 \mathrm{~mm}$

109 of rainfall and $248 \mathrm{~mm}$ of snowfall) and mean daily temperature was $1.2^{\circ} \mathrm{C}$, with an average of 2334

110 degree-days above $0^{\circ} \mathrm{C}$ (Environment Canada 2010). Clayey soils and fine-grained sediments are

111 associated with glaciolacustrine deposits from the maximum post-Wisconsonian extension of

112 proglacial lakes Barlow and Objibway (10100 - 8000 years before present; Veillette, 1994). Both

113 stands were not subjected to any silvicultural treatment and originated from stand-replacing fires.

114 Stand characteristics of the surveyed sites are shown in Table 1.

115 In total, 154 trees were felled and excavated in summer 2011, 97 of them were alive. Dead trees were

116 discarded and 36 trees were selected for this study (18 trees per site). Twelve pairs of grafted trees

117 and 12 non-grafted trees were selected (six pairs of grafted trees and six non-grafted trees per site).

118 Sample size was limited by the number of non-grafted trees given that most excavated trees were

119 grafted (see Table 1), and non-grafted trees in the edge of the excavated area were discarded. Non-

120 grafted trees were selected according to their spatial location to confirm that their roots do not grow

121 beyond the excavated area and do not form grafts. Each pair of grafted trees was composed of a

122 dominant and a suppressed tree to evaluate different responses to defoliation depending on tree size

123 (see Baret and DesRochers, 2011). Of the 12 non-grafted trees, six trees were dominant and six

124 suppressed. Trees were felled with a chain saw and cross-sectional disks were cut at ground level $(0$ 
125

126

127

128

130

\section{1}

132

133

$\mathrm{m})$ and at breast height $(1.30 \mathrm{~m})$ for age determination. To allow hydraulic excavation of the root systems, plots were located near a pond and a forestry water pump (Mark III, Wajax, Lachine, QC) was used to expose the root systems. The excavated areas covered 110 and $200 \mathrm{~m}^{2}$ (Table 1). Sketches depicting trees, roots, and grafts were drawn by hand. Detailed protocols for hydraulic excavation and field sampling can be found in Tarroux and DesRochers (2010).

\section{Laboratory work}

Cross-sectional disks were air-dried and progressively sanded (80-400 grit paper) to clearly reveal growth rings. Razor blades and white chalk were punctually used for better accuracy in particularly problematic sections. Root grafts were dissected with a band saw to examine their anatomy and uniquely functional intraspecific grafts, involving morphological union of cambium, phloem, and xylem (Graham and Bormann 1966), were considered for analyses. To estimate the period of graft formation within each pair of grafted trees, the first and the last year of graft formation were determined among several root disks along the root graft as in Tarroux and DesRochers (2010). Cross-sectional disks at ground level $(0 \mathrm{~m})$ were used for ring-width measurements and disks at breast height $(1.30 \mathrm{~m})$ were used to cross-date and validate tree age in case of aberrant features (e.g. eccentric growth, and missing/discontinuous growth rings). Ring-width series from the center pith to the outermost ring of each disk were measured on four radii (when possible) using a Velmex unislide measuring table (Velmex Inc., Bloomfield, NY) interfaced with a computer. The first measurement radius was positioned at $22.5^{\circ}$ from the longest cross-sectional disk radius and the three consecutive measurement radii were perpendicular to the first one (Zarnovican 1985). COFECHA (GrissinoMayer 2001) and TSAPWin (RINNTECH, Engineering and Distribution, Heidelberg, Germany) programs were used to verify tree-ring radial growth series. Ring-width chronologies were standardized using ARSTAN (Grissino-Mayer 2001) to minimize related effects of tree size and age, which were out of the scope of this research. 


\section{Statistical analyses}

150 Spruce budworm outbreak and root grafting intensity

151 To detect the last budworm event at the study sites, the OUTBREAK program was used (V1.50,

152 Holmes and Swetnam 1996). The program identifies occurrence of spruce budworm attacks in series

153 of annual tree-ring width measurements and quantifies the length and severity of the outbreak for

154 each tree. A control non-host chronology based on three naturally regenerated jack pine stands (Pinus

155 banksiana Lamb.) located near the experimental plots (Tarroux and DesRochers 2010) was used to

156 detect growth reductions due to spruce budworm by comparison of radial growth curves between

157 host and non-host species. The percentage of grafted trees was calculated as the cumulative

158 percentage of trees that started to form root grafts (and remained connected) over the 12 pairs of

159 grafted trees. The number of grafts being formed was calculated as the yearly frequency of graft

160 formation among grafted trees.

\section{Effect of dominance status and root grafting on tree growth}

162 Statistical analyses were performed in R (v.3.1.1) and model assumptions were tested and verified. To

163 analyse how tree growth was affected by the outbreak according to tree status, we compared tree

164 growth before, during and after the 1970s outbreak between dominant and suppressed trees. First, as

165 the period of maximum defoliation intensity lasted six years, cumulative radial growth of the six

166 years before, during and after the outbreak was compared using a linear mixed model with the lme

167 function in the nlme library (Pinheiro et al. 2008). Linear mixed models differentiate between fixed

168 and random effects to consider the error structure for longitudinal, clustered or repeated

169 measurements. Tree status (dominant or suppressed), period (before, during and after the outbreak)

170 and their interaction were fixed as categorical factors (model CUM_STATUS). To avoid sacrificial

171 pseudo-replication error (data from different experimental units are used as independent replicates 
172 and pooled in the same analysis) (Hurlbert 1984), radii were nested within their corresponding tree

173 and trees were nested within their corresponding site, and were considered as random factors.

174 Backward selection tested the model containing all the variables (global model) and removed the

175 least significant variable until all variables included in the model were significant $(p<0.05)$. Second,

176 we studied yearly radial growth using a linear mixed model with the lme function and the lmer

177 function in the lme4 library (model YEAR_STATUS; Bates et al. 2014) in which tree status, year and

178 their interaction were fixed as categorical factors. Radii, trees and sites were nested random factors.

179 Since sampled trees were not even-aged, only the time span since the youngest tree emergence was

180 considered (from 1967 to 2011). The temporal series were split into shorter temporal sets of five

181 years to avoid a qualitative factor with 45 categories. As yearly growth values are not independent

182 from one another (growth of year $t$ is affect by growth of year $\mathrm{t}-1$ ), a first order autoregressive

183 correlation structure was used (Grissino-Mayer 2001, Pinheiro et al. 2008). To detect growth

184 differences between dominant and suppressed trees within single years, contrasts were performed

185 using the glht function in the multcomp library (Hothorn et al. 2008).

186 To assess the influence of root grafting on tree growth in relation to the outbreak, dominant and

187 suppressed trees were separately analysed to concentrate the analysis on the differences between

188 grafted and non-grafted trees within the same stratum. To compare cumulative and yearly growth

189 between grafted and non-grafted trees, linear mixed models were similarly adjusted to

190 CUM_STATUS and YEAR_STATUS by substituting the categorical factor tree status by grafting

191 presence (grafted or non-grafted) in both dominant (CUM_DOM and YEAR_DOM) and suppressed

192 trees (CUM_SUP and YEAR_SUP).

\section{Results}

194 The last spruce budworm outbreak negatively affected tree growth in the 1970s, reaching a maximum

195 of infested trees between 1973 and 1978 (up to 86\%; Fig. 1). Among the 12 pairs of grafted trees, the 
196 cumulative percentage of grafted trees increased from $42 \%$ to $58 \%$ during the period of maximum

197 defoliation (Fig. 1). The yearly percentage of infested trees was directly related to the number of

198 grafts being formed during the same year (Pearson's correlation $=0.429 ; p=0.002$ ). This correlation 199 progressively improved considering lagged regressions up to seven years (Pearson's correlation $=$ $200 \quad 0.649 ; p<0.001)$

201 Dominant and suppressed trees established at the same time $(p=0.23)$, and tree basal diameter 202 before the outbreak (1972) was similar between dominant and suppressed trees $(p>0.05)$.

203 Eventually, dominant trees were bigger than suppressed trees at the time of excavation in $2011(p<$ 204 0.001), with the average tree radius at ground level $93.2 \pm 5.4$ and $46.9 \pm 4.5 \mathrm{~mm}(\mathrm{mean} \pm$ s.e.) for 205 dominant and suppressed trees, respectively. The cumulative radial growth of the six years before, 206 during and after the outbreak was not influenced by tree status (dominant or suppressed) or its 207 interaction with the surveyed period $(p>0.05)$. Growth decreased during the outbreak and increased 208 after it $(p<0.001)$. Results on yearly radial growth before, during and after the outbreak corroborate 209 the results obtained for cumulative growth (Fig. 2). Yearly radial growth decreased from 1973 to 210 1978, with the maximum growth reduction encountered in 1976; immediately after the outbreak, 211 radial growth increased to pre-outbreak levels (Fig. 2). Suppressed trees showed significant growth 212 reductions from 1990 to 2005 ( $p<0.05$; Fig. 2 and Table S1).

213 Among dominant trees, cumulative growth of grafted trees showed no decrease during the outbreak $214(p=0.487)$, and a significant growth increase was observed after it $(p=0.016 ;$ Fig. 3a). Contrarily, 215 cumulative growth decreased during the outbreak for dominant non-grafted trees $(p<0.001)$, and 216 remained constant after the outbreak $(p=0.119$; Fig. 3a). Differences in cumulative growth between 217 dominant grafted and non-grafted trees within the same period were not observed (Fig 3a); although 218 non-grafted trees tended to have higher growth before the outbreak $(p=0.067)$. Yearly growth of 219 dominant grafted trees was lower than growth of dominant non-grafted trees in 1971 and 1972 (Fig. 
220 4a and Table S2) while it was similar during and immediately after the outbreak. Growth of grafted

221 trees increased to higher rates than non-grafted trees in 1988 and 1989, whereas non-grafted trees

222 showed higher growth in 2007 (Fig. 4a).

223 Among suppressed trees, cumulative growth of grafted trees remained roughly constant before, 224 during and after outbreak (Fig. 3b). Cumulative growth of non-grafted trees was significantly lower 225 during outbreak event compared to before the defoliation $(p<0.001$; Fig. 3b). Within the same 226 period, cumulative growth of supressed grafted and non-grafted trees was similar (Fig. 3b); however, 227 grafted trees tended to have higher growth during the outbreak $(p=0.083)$. Differences in yearly 228 radial growth between grafted and non-grafted trees within the suppressed stratum were only 229 significant in 1990 when grafted trees exhibited larger growth than non-grafted trees (Fig. 4b and 230 Table S2).

\section{Discussion}

\section{Root grafts to cope with outbreaks}

233 Despite the fact that grafted and non-grafted trees were even-sized prior to the outbreak, cumulative 234 growth of grafted trees remained roughly stable during the outbreak relative to pre-disturbance 235 values, whereas non-grafted trees suffered growth reductions, for both dominant and suppressed 236 status. Furthermore, cumulative growth of dominant grafted trees was released immediately after the 237 outbreak, whilst growth of dominant non-grafted trees after the outbreak did not increase relative to 238 the outbreak period. These results suggest that root grafts attenuate the effect of insect defoliation in 239 tree growth. Grafted trees can share resources, namely water and nutrients (Stone and Stone 1975, 240 Fraser et al. 2006), and communal root systems allow maximum efficiency to capture and distribute 241 resources among connected trees that may lead to increased stem growth (Tarroux and DesRochers 242 2010). Moreover, as carbohydrates can be transferred through root grafts, larger and shared 
243 carbohydrate pools may contribute to the better performance of grafted trees to face outbreaks after

244 carbon depletion that firstly occurs in non-grafted trees (see Fig. 1 in Fraser et al. 2006). An

245 attenuated effect of budworm outbreak in grafted trees supports the hypothesis that common

246 functioning of genetically distinct individuals can overcome the death of weaker trees (Basnet et al.

247 1993, DesRochers and Lieffers 2001, Fraser et al. 2005, 2006, Tarroux et al. 2010) as a competitive

248 strategy to impede recruitment of different species (Tarroux and DesRochers 2011). Consistently,

249 graft formation lagged behind the outbreak up to seven years suggesting that defoliation might be the

250 underpinning trigger of graft formation in black spruce (see Loehle and Jones 1990). However, this is

251 not necessarily a cause-effect relationship and manipulative tests may help to further examine this

252 idea.

253 Notwithstanding, significant differences between grafted and non-grafted trees were not observed

254 before, during or immediately after the outbreak indicating a moderate influence of root grafting in

255 tree growth in response to defoliation. In any case, it is worth noting that during the epidemic period

256 (1973-1978), weaker trees that eventually became suppressed tended to have greater growth if

257 grafted $(p=0.083)$. This significance level $(\alpha=0.10)$ might be reasonable to detect actual differences

258 given the limited sample size in this study, constrained by methodological difficulties related to the

259 excavation of forest soils. Similarly, limited sample size also reduces the likelihood that a significant

260 result reflects an actual effect, and differences observed in this study should be taken with caution.

261 On the other hand, although root grafting seems favourable to persist under frequent outbreak

262 regimes, drawbacks of root grafting in stem growth were detected under more favourable conditions,

263 i.e. prior to outbreak and after stand recovery, when carbon supply was not curtailed by insect

264 defoliation. Among dominant trees, yearly growth reductions of grafted trees were observed

265 immediately before (1971 and 1972) and long after the outbreak (2007). Tarroux and DesRochers

266 (2011) observed that during periods of root graft formation, grafting tended to reduce radial growth in 
267 jack pines as root grafting is an energetically costly process. Carbon investment for graft constitution 268 and callus formation might contribute to reduce growth of grafted trees immediately before and long 269 after defoliation, when outbreak may not compromise tree growth. Furthermore, carbohydrate supply 270 from dominant to suppressed connected trees - and even grafted stumps and roots without aerial 271 counterparts (DesRochers and Lieffers 2001, Tarroux and DesRochers 2010, Tarroux et al. 2010, 272 Salomón et al. 2016) - might also constrain stem growth of dominant grafted trees under favourable 273 conditions. In this line, vertical development of stems and crowns to compete for aboveground 274 resources might be unnecessary among trees extensively and horizontally connected, and so non275 competitive forces may govern growth dynamics among physiologically connected individuals 276 (Basnet et al. 1993, Baret and DesRochers 2011) favouring carbon allocation to storage. A 277 278 budworm outbreaks, hence reflecting a trade-off between aboveground performance and persistence among grafted trees. Summarizing, reduced growth of dominant grafted trees not constrained by budworm defoliation might be partially explained by (i) carbon investment in graft formation, (ii) carbon donation to maintain suppressed grafted trees, and (iii) a conservative strategy of carbon storage.

\section{Budworm outbreak and stand dynamics}

Balsam fir and white spruce are commonly the preferred hosts of the spruce budworm (Morin et al. 2007), even so the last outbreak in Québec caused defoliation of 55 million ha of black spruce stands (Fierravanti et al. 2015). In the surveyed sites, $85 \%$ of the black spruces were defoliated between 1973 and 1978, reaching rates of defoliation as high as in fir dominated forests, and with maximum growth reductions in 1976. Our results corroborate the closest study performed in lake Duparquet (Abitibi region, Quebec) in white spruce in which important growth reductions occurred between 
2911973 and 1977 (Morin et al. 1993). Similarly, insect defoliation in black spruce were noticed by 292 dendrochronology and photointerpretation in lakes Libéral and Onatchiway between 1976 and 1979 293 (Krause and Morin 1999), and in Lac Lamandonis around 1980 (Bouchard et al. 2007). At a wider 294 spatial scale, this event corresponds to the well-documented last spruce budworm outbreak in Québec 295 in the $20^{\text {th }}$ century (e.g. Morin et al., 1993, 2007; Krause and Morin, 1999; Bouchard et al., 2007; 296 Simard et al., 2008; Boulanger et al., 2012; Fierravanti et al., 2015).

297 Tree mortality following periodic outbreaks results in canopy gaps that govern recruitment dynamics 298 and tree growth patterns in boreal forests in eastern Canada (Morin 1994, Bouchard et al. 2007). In 299 the surveyed sites, significant growth reductions during the outbreak and growth releases 300 immediately after it were observed in both dominant and suppressed trees. Before the outbreak, trees 301 that would become dominant and suppressed at the time of excavation (2011) were even-sized, but 302 the outbreak might have triggered differential growth between them. Since the impact of budworm 303 defoliation in stand development lengthens far beyond the outbreak (Colford-Gilks et al. 2012), 304 differential growth between potential dominant and suppressed trees (1990-2005) lagged 12 years 305 behind the period of highest outbreak intensity (1973-1978). Accordingly, the post-outbreak impact 306 in balsam fir has been observed to persist during wide temporal spans: e.g., six years in relation to 307 tree growth (Pothier et al. 2005), and 11-15 years (Taylor and MacLean 2009) and up to 35 years in 308 relation to tree mortality (MacLean and Andersen 2008). Enhanced carbon allocation to storage 309 (Salomón et al. 2016), and use of starch reserves to fuel metabolism over periods of limited carbon 310 supply (Bhupinderpal-Singh et al. 2003, Aubrey et al. 2012) and to resprout in cases of canopy 311 dieback is the life strategy of species subjected to frequent disturbance regimes (Bond and Midgley 312 2001). In the specific case of black spruce, the use of starch reserves by roots can extend over time 313 for up to six years, as demonstrated by radiocarbon signatures $\left(\Delta^{14} C\right)($ Czimczik et al. 2006, Schuur 314 and Trumbore 2006). Thus, a conservative allocation pattern of carbohydrates in black spruce could 
315 contribute to the delayed effect of defoliation in stem growth that eventually led to the current stand 316 structure.

317 Beyond the outbreak, yearly growth of dominant grafted trees was higher relative to dominant non318 grafted trees in 1988 and 1989; subsequently, growth of suppressed grafted trees was higher relative 319 to suppressed non-grafted trees (in 1990). As similarly observed in lodgepole pine after manipulative 320 shading (Fraser et al. 2006), suppressed grafted trees may have benefited from the preceding (and 321 comparatively enhanced) growth of dominant grafted trees by carbohydrate transfer from higher to 322 lower strata, carbon source and sink, respectively. Again, the positive effect of root grafting in stem 323 growth was observed after several years of limited carbon supply, coinciding with the first symptoms 324 of carbon depletion exhibited by suppressed trees.

\section{Conclusions}

326 Root grafts slightly attenuated the negative effects of defoliation in black spruce during and 327 immediately after spruce budworm outbreak. Moreover, graft formation lagged behind insect 328 defoliation by seven years suggesting that root grafting might be fostered under scenarios of limited 329 carbon supply. Root grafting may be a cooperative strategy to face insect defoliation and it might 330 play an important role in stand dynamics in areas subjected to periodic outbreaks. The classic concept 331 of trees as discrete identities competing for light and soil resources should be revisited.

\section{Acknowledgements}

333 We are grateful to technicians and trainees who helped in field and laboratory work. María Valbuena 334 Carabaña and Luis Gil also contributed with valuable discussions. We also thank two anonymous 335 reviewers for comments that improved the manuscript. This work was supported by the Natural 336 Sciences and Engineering Research Council of Canada (NSERC-CRSNG) through a Collaborative 337 and Research Development grant [grant number CRDPJ 429776 - 11] to AD, in collaboration with 
338 the NSERC-UQAT-UQAM Industrial Chair in Sustainable Forest Management and Matériaux

339 Blanchet Inc. Universidad Politécnica de Madrid supported RS with a PhD grant and also financed 340 his short stay in the UQAT.

341 


\section{References}

Aubrey, D.P., Mortazavi, B., O’Brien, J.J., McGee, J.D., Hendricks, J.J., Kuehn, K.A., Teskey, R.O., and Mitchell, R.J. 2012. Influence of repeated canopy scorching on soil CO2 efflux. For. Ecol. Manage. 282: 142-148. doi:10.1016/j.foreco.2012.06.041.

Baret, M., and DesRochers, A. 2011. Root connections can trigger physiological responses to defoliation in nondefoliated aspen suckers. Botany 89(11): 753-761. doi:10.1139/b11-062.

Basnet, K., Scatena, F., Likens, G., and Lugo, A. 1993. Ecological consequences of root grafting in Tabonuco (Dacryoides excelsa) trees in the Luquillo experimental forest, Puerto Rico. Biotropica 25(1): 28-35. Available from http://www.jstor.org/stable/2388976.

Bates, D., Maechler, M., Bolker, B., and Walker, S. 2014. lme4: Linear mixed-effects models using Eigen and S4. R package version 1.1-10. Available from http://cran.r-project.org/package=lme4.

Bergeron, Y., Leduc, A., Morin, H., and Joyal, C. 1995. Balsam fir mortality following the last spruce budworm outbreak in northwestern Quebec. Can. J. For. Res. 25(8): 1375-1384. doi:10.1139/X95-150.

Bhupinderpal-Singh, Nordgren, A., Ottosson Löfvenius, M., Högberg, M.N., Mellander, P.-E., and Högberg, P. 2003. Tree root and soil heterotrophic respiration as revealed by girdling of boreal Scots pine forest: extending observations beyond the first year. Plant, Cell Environ. 26(8): 1287-1296. doi:10.1046/j.1365-3040.2003.01053.x.

Bond, W.J., and Midgley, J.J. 2001. Ecology of sprouting in woody plants: the persistence niche. Trends Ecol. Evol. 16(1): 45-51. doi:10.1016/S0169-5347(00)02033-4.

Bouchard, M., Kneeshaw, D., and Messier, C. 2007. Forest dynamics following spruce budworm outbreaks in the northern and southern mixedwoods of central Quebec. Can. J. For. Res. 37(4): 763-772. doi:10.1139/X06-278. 
Boulanger, Y., and Arseneault, D. 2004. Spruce budworm outbreaks in eastern Quebec over the last 450 years. Can. J. For. Res. 34(5): 1035-1043. doi:10.1139/x03-269.

Boulanger, Y., Arseneault, D., Morin, H., Jardon, Y., Bertrand, P., and Dagneau, C. 2012. Dendrochronological reconstruction of spruce budworm (Choristoneura fumiferana) outbreaks in southern Quebec for the last 400 years. Can. J. For. Res. 42: 1264-1276. doi:10.1139/X2012069.

Boulet, B., Chabot, M., Dorais, L., Dupont, A., and Gagnon, R. 1996. Entomologie forestière. In Manuel de Foresterie. Edited by Ordre des Ingénieurs Forestiers. Sainte-Foy, Québec: Les Presses de 1'Université Laval. pp. 1008-1043.

Campbell, E.M., MacLean, D.A., and Bergeron, Y. 2008. The severity of budworm-caused growth reductions in balsam fir/spruce stands varies with the hardwood content of surrounding forest landscapes. For. Sci. 54(2): 195-205. Available from http://www.ingentaconnect.com/content/saf/fs/2008/00000054/00000002/art00009.

Colford-Gilks, A.K., MacLean, D.A., Kershaw, J.A., and Béland, M. 2012. Growth and mortality of balsam fir- and spruce-tolerant hardwood stands as influenced by stand characteristics and spruce budworm defoliation. For. Ecol. Manage. 280: 82-92. doi:10.1016/j.foreco.2012.05.023.

Czimczik, C.I., Trumbore, S.E., Carbone, M.S., and Winston, G.C. 2006. Changing sources of soil respiration with time since fire in a boreal forest. Glob. Chang. Biol. 12(6): 957-971. doi:10.1111/j.1365-2486.2006.01107.x.

DesRochers, A., and Lieffers, V.J. 2001. The coarse-root system of mature Populus tremuloides in declining stands in Alberta, Canada. J. Veg. Sci. 12(3): 355-360. doi:10.2307/3236849.

Eis, S. 1972. Root Grafts and their Silvicultural Implications. Can. J. For. Res. 2(2): 111-120. doi:10.1139/x72-022. 
Environment Canada. 2010. National climate archives. Available from http://climate.weather.gc.ca/ [accessed 10 December 2015].

Fierravanti, A., Cocozza, C., Palombo, C., Rossi, S., Deslauriers, A., and Tognetti, R. 2015. Environmental-mediated relationships between tree growth of black spruce and abundance of spruce budworm along a latitudinal transect in Quebec, Canada. Agric. For. Meteorol. 213: 5363. doi:10.1016/j.agrformet.2015.06.014.

Fraser, E.C., Lieffers, V.J., and Landhäusser, S.M. 2005. Age, stand density, and tree size as factors in root and basal grafting of lodgepole pine. Can. J. Bot. 83(8): 983-988. doi:10.1139/b05-048.

Fraser, E.C., Lieffers, V.J., and Landhäusser, S.M. 2006. Carbohydrate transfer through root grafts to support shaded trees. Tree Physiol. 26: 1019-1023. doi:10.1093/treephys/26.8.1019.

Graham, B.F., and Bormann, F.H. 1966. Natural Root Grafts. Bot. Rev. 32(3): 255-292. New York Botanical Garden Press. Available from http://www.jstor.org/stable/4353731.

Grissino-Mayer, H.D. 2001. Evaluating crossdating accuracy: A manual and tutorial for the computer program COFECHA. Tree-Ring Res. 57(2): 205-221. Available from http://arizona.openrepository.com/arizona/handle/10150/251654.

Grondin, P., Ansseau, C., Bélanger, L., Bergeron, J.F., Bergeron, Y., Bouchard, A., Brisson, J., De Grandpré, L., Gagnon, G., and Lavoie, C. 1996. Écologie forestière. In Manuel de foresterie. Edited by J. Bérard and M. Côté. Presses de l’Université Laval Sainte-Foy, Québec. pp. 133279.

Holmes, R.L., and Swetnam, T.W. 1996. Dendroecology Program Library: Program OUTBREAK User's Manual. Laboratory of Tree-Ring Research, University of Arizona., Tucson. Available from http://web.utk.edu/ grissino/. 
Hothorn, T., Bretz, F., and Westfall, P. 2008. Simultaneous inference in general parametric models. Biometrical J. 50(3): 346-363. doi:10.1002/bimj.200810425.

Hurlbert, S. 1984. Pseudoreplication and the design of ecological field experiments. Ecol. Monogr. 54(2): 187-211. doi:10.2307/1942661.

Krause, C., and Morin, H. 1999. Tree-ring patterns in stems and root systems of black spruce (Picea mariana) caused by spruce budworms. Can. J. For. Res. 29(10): 1583-1591. doi:10.1139/cjfr29-10-1583.

Lev-Yadun, S. 2011. Why should trees have natural root grafts? Tree Physiol. 31(6): 575-578. doi:10.1093/treephys/tpr061.

Loehle, C., and Jones, R.H. 1990. Adaptive significance of root grafting in trees. Funct. Ecol. 4: 268271. Available from http://www.jstor.org/stable/2389347.

MacKinnon, W.E., and MacLean, D.A. 2004. Effects of surrounding forest and site conditions on growth reduction of balsam fir and spruce caused by spruce budworm defoliation. Can. J. For. Res. 34(11): 2351-2362. doi:10.1139/x04-115.

MacLean, D.A., and Andersen, A.R. 2008. Impact of a spruce budworm outbreak in balsam fir and subsequent stand development over a 40-year period. For. Chron. 84(1): 60-69. doi:10.5558/tfc84060-1.

Morin, H. 1994. Dynamics of balsam fir forests in relation to spruce budworm outbreaks in the Boreal Zone of Quebec. Can. J. For. Res. 24(4): 730-741. doi:10.1139/x94-097.

Morin, H., Jardon, Y., and Gagnon, R. 2007. Relationship between spruce budworm outbreaks and forest dynamics in eastern North America. In Plant Disturbance Ecology. The Process and the Response. Edited by E.A. Jonhson and K. Miyanishi. Academic Press, Elsevier, London. pp. 
555-577.

Morin, H., Laprise, D., and Bergeron, Y. 1993. Chronology of spruce budworm outbreaks near Lake Duparquet, Abitibi region, Quebec. Can. J. For. Res. 23(8): 1497-1506. doi:10.1139/x93-189.

Palacio, S., Hoch, G., Sala, A., Körner, C., and Millard, P. 2014. Does carbon storage limit tree growth? New Phytol. 201(4): 1096-1100. doi:10.1111/nph.12602.

Pinheiro, J., Bates, D., DebRoy, S., Sarkar, D., and Team, R.C. 2008. nlme: linear and nonlinear mixed effects models. R Foundation for Statistical Computing, Vienna, Austria. Available from http://cran.r-project.org/web/packages/nlme/index.html.

Pothier, D., Elie, J.-G., Auger, I., Mailly, D., and Gaudreault, M. 2012. Spruce budworm-caused mortality to balsam fir and black spruce in pure and mixed conifer stands. For. Sci. 58(1): 2433. doi:10.5849/forsci.10-110.

Pothier, D., and Mailly, D. 2006. Stand-level prediction of balsam fir mortality in relation to spruce budworm defoliation. Can. J. For. Res. 36(7): 1631-1640. doi:10.1139/x06-062.

Pothier, D., Mailly, D., and Tremblay, S. 2005. Predicting balsam fir growth reduction caused by spruce budworm using large-scale historical records of defoliation. Ann. For. Sci. 62: 261-267. doi:10.1051/forest.

Salomón, R., Rodríguez-Calcerrada, J., Zafra, E., Morales-Molino, C., Rodríguez-García, A., González-Doncel, I., Oleksyn, J., Zytkowiak, R., López, R., Miranda, J.C., Gil, L., and Valbuena-Carabaña, M. 2016. Unearthing the roots of degradation of Quercus pyrenaica coppices: A root-to-shoot imbalance caused by historical management? For. Ecol. Manage. 363: 200-211. doi:10.1016/j.foreco.2015.12.040.

Schuur, E.A.G., and Trumbore, S.E. 2006. Partitioning sources of soil respiration in boreal black 
spruce forest using radiocarbon. Glob. Chang. Biol. 12(2): 165-176. doi:10.1111/j.13652486.2005.01066.x.

Simard, S., Elhani, S., Morin, H., Krause, C., and Cherubini, P. 2008. Carbon and oxygen stable isotopes from tree-rings to identify spruce budworm outbreaks in the boreal forest of Québec. Chem. Geol. 252(1-2): 80-87. doi:10.1016/j.chemgeo.2008.01.018.

Stone, J.E., and Stone, E.L. 1975. The communal root system of red pine: water conduction through root grafts. For. Sci. 21(3): 255-261. Available from http://www.ingentaconnect.com/content/saf/fs/1975/00000021/00000003/art00012.

Tarroux, E., and DesRochers, A. 2010. Frequency of root grafting in naturally and artificially regenerated stands of Pinus banksiana: influence of site characteristics. Can. J. For. Res. 40(5): 861-871. doi:10.1139/X10-038.

Tarroux, E., and DesRochers, A. 2011. Effect of natural root grafting on growth response of jack pine (Pinus banksiana; Pinaceae). Am. J. Bot. 98(6): 967-974. doi:10.3732/ajb.1000261.

Tarroux, E., DesRochers, A., and Krause, C. 2010. Effect of natural root grafting on growth response of jack pine (Pinus banksiana) after commercial thinning. For. Ecol. Manage. 260(4): 526-535. doi:10.1016/j.foreco.2010.05.008.

Taylor, S.L., and MacLean, D.A. 2009. Legacy of insect defoliators: Increased wind-related mortality two decades after a spruce budworm outbreak. For. Sci. 55(3): 256-267. Available from http://www.ingentaconnect.com/content/saf/fs/2009/00000055/00000003/art00008.

Veillette, J.J. 1994. Evolution and paleohydrology of glacial Lakes Barlow and Ojibway. Quat. Sci. Rev. 13(9-10): 945-971. doi:10.1016/0277-3791(94)90010-8.

Wiley, E., and Helliker, B. 2012. A re-evaluation of carbon storage in trees lends greater support for 
carbon limitation to growth. New Phytol. 195(2): 285-289. doi:10.1111/j.14698137.2012.04180.x.

Zarnovican, R. 1985. Analyse de tige: une méthode à redécouvrir. Nat. Canada 112: 253-260. Available from http://cfs.nrcan.gc.ca/publications?id=14305. 
Table 1. Characteristics of two excavated plots dominated by black spruce naturally regenerated.

\begin{tabular}{|c|c|c|}
\hline & Site 1 & Site 2 \\
\hline Stand density (trees ha ${ }^{-1}$ ) & 4727 & 2250 \\
\hline Dominant height $(\mathrm{m})$ & 13.3 & 18.6 \\
\hline Excavated area $\left(\mathrm{m}^{2}\right)$ & 110 & 200 \\
\hline Number of excavated trees & 93 & 61 \\
\hline Number of excavated living trees & 52 & 45 \\
\hline Number of grafted trees & 34 & 35 \\
\hline Mean diameter $(\mathrm{cm})^{*}$ & \multicolumn{2}{|c|}{$12.2 \pm 1.3 \quad 15.8 \pm 1.6$} \\
\hline Mean tree age (years)* & $73.7 \pm 5.9$ & $76.3 \pm 2.4$ \\
\hline
\end{tabular}

* Note that the number of excavated trees, excavated living trees, and excavated grafted trees differ from the number of surveyed trees for this study (18 per site). Mean ( \pm s.e.) tree diameter (at ground level) and tree age refer to surveyed trees at the time of excavation in 2011. 
Fig. 1. Grafting occurrence in two excavated sites dominated by black spruce, and spruce budworm outbreak intensity quantified by the percentage of defoliated trees.

Percentage of infested trees was obtained using OUTBREAK program comparing tree-ring series between host (black spruce) and non-host species (jack pine). The percentage of grafted trees is calculated as the cumulative percentage of trees that started to form root grafts (and remained connected) over the 12 pairs of grafted trees. The number of grafts being formed exhibits the yearly frequency of graft formation among grafted trees.

Fig. 2. Yearly radial growth of dominant and suppressed trees in the excavated sites.

The surveyed period was split in temporal sets of five years. The vertical shaded area indicates the outbreak period (1973-1978). Growth estimates and standard errors are depicted. Symbols indicate a significant difference between dominant and suppressed trees: $* * *<0.001 ; * *<0.01 ; *<0.05 ; \bullet<$ 0.1 .

Fig. 3. Cumulative radial growth of grafted and non-grafted trees among dominant (a) and suppressed (b) status before (from 1967 to 1972), during (from 1973 to 1978), and immediately after the outbreak (from 1979 to 1984).

Different letters indicate significant differences $(p<0.05)$ in cumulative growth across the surveyed periods and between grafted and non-grafted trees.

Fig. 4. Differences in yearly radial growth between grafted and non-grafted trees among dominant (a) and suppressed (b) status.

The surveyed period was split in temporal sets of five years. The vertical shaded area indicates the outbreak period (1973-1978). Growth estimates and standard errors of the contrasts are depicted. Symbols indicate a significant difference between grafted and non-grafted trees: $* *<0.01 ; *<0.05$; $\bullet<0.1$ 


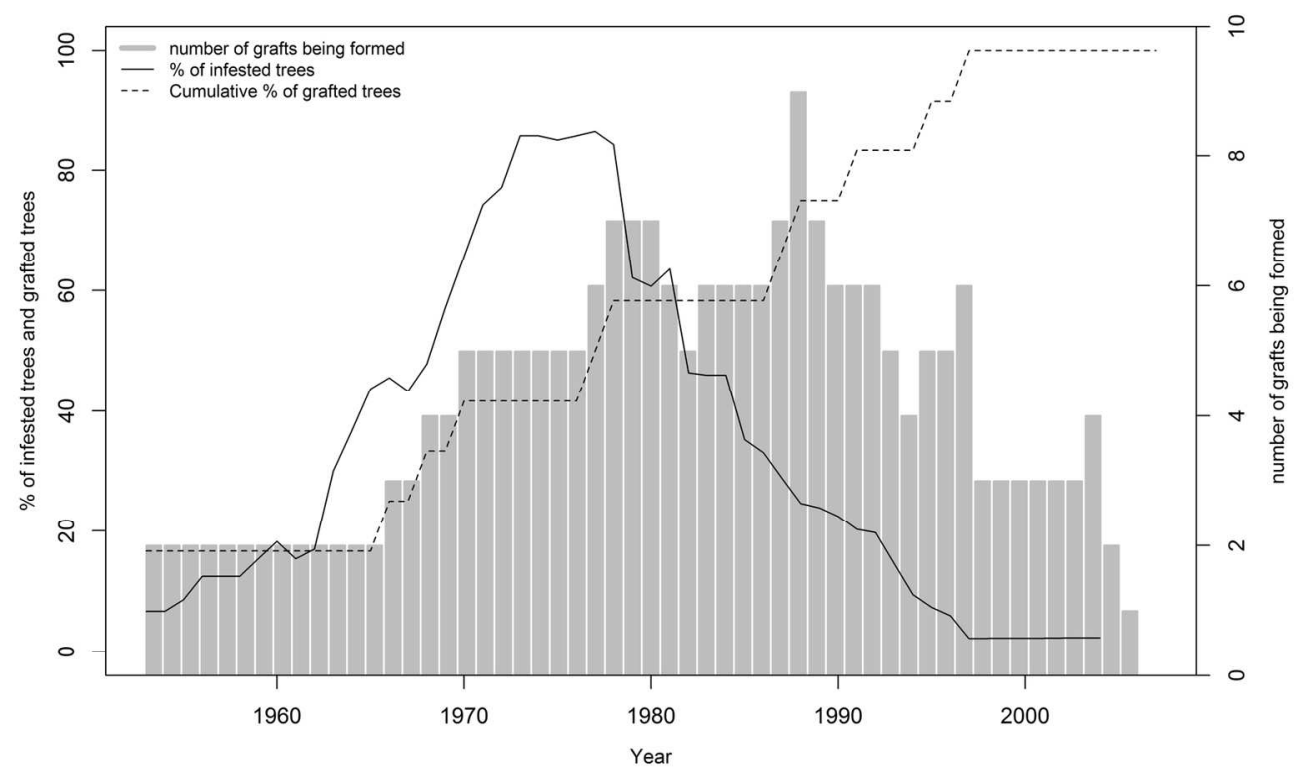

Grafting occurrence in two excavated sites dominated by black spruce, and spruce budworm outbreak intensity quantified by the percentage of defoliated trees. $149 \times 90 \mathrm{~mm}(300 \times 300 \mathrm{DPI})$ 


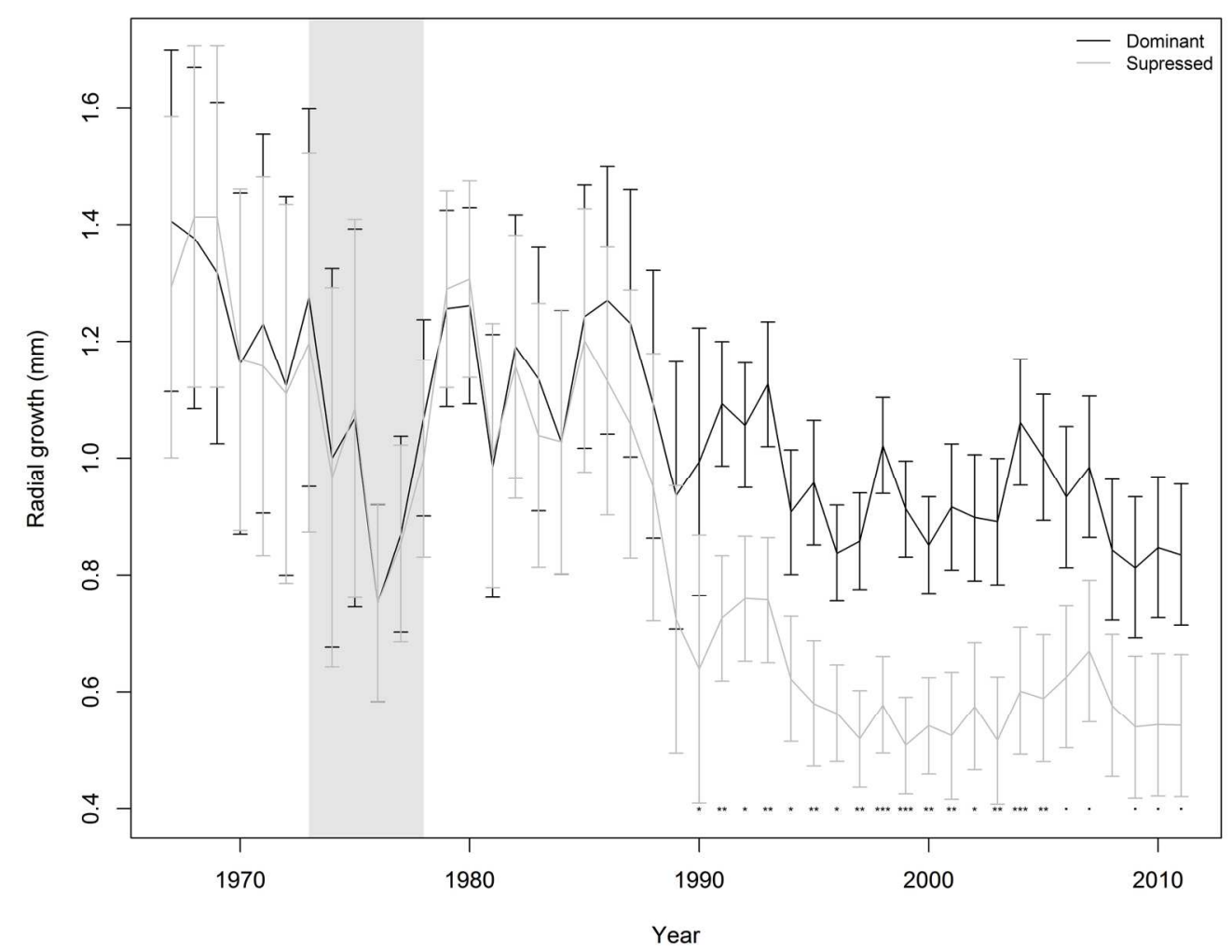

Yearly radial growth of dominant and suppressed trees in the excavated sites. $174 \times 136 \mathrm{~mm}(300 \times 300 \mathrm{DPI})$ 


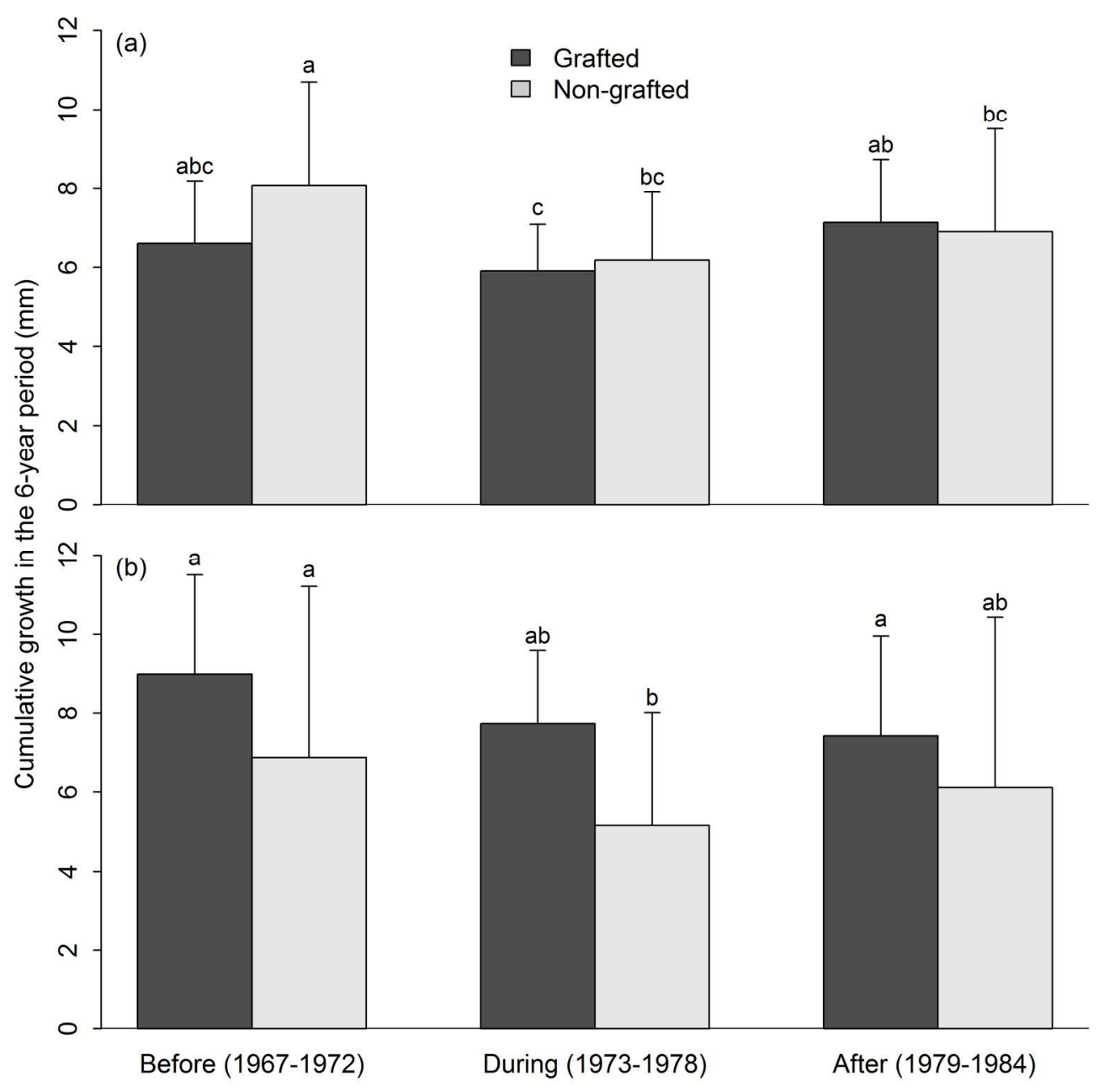

Cumulative radial growth of grafted and non-grafted trees among dominant (a) and suppressed (b) status before (from 1967 to 1972), during (from 1973 to 1978), and immediately after the outbreak (from 1979 to 1984).

$179 \times 179 \mathrm{~mm}(300 \times 300$ DPI $)$ 


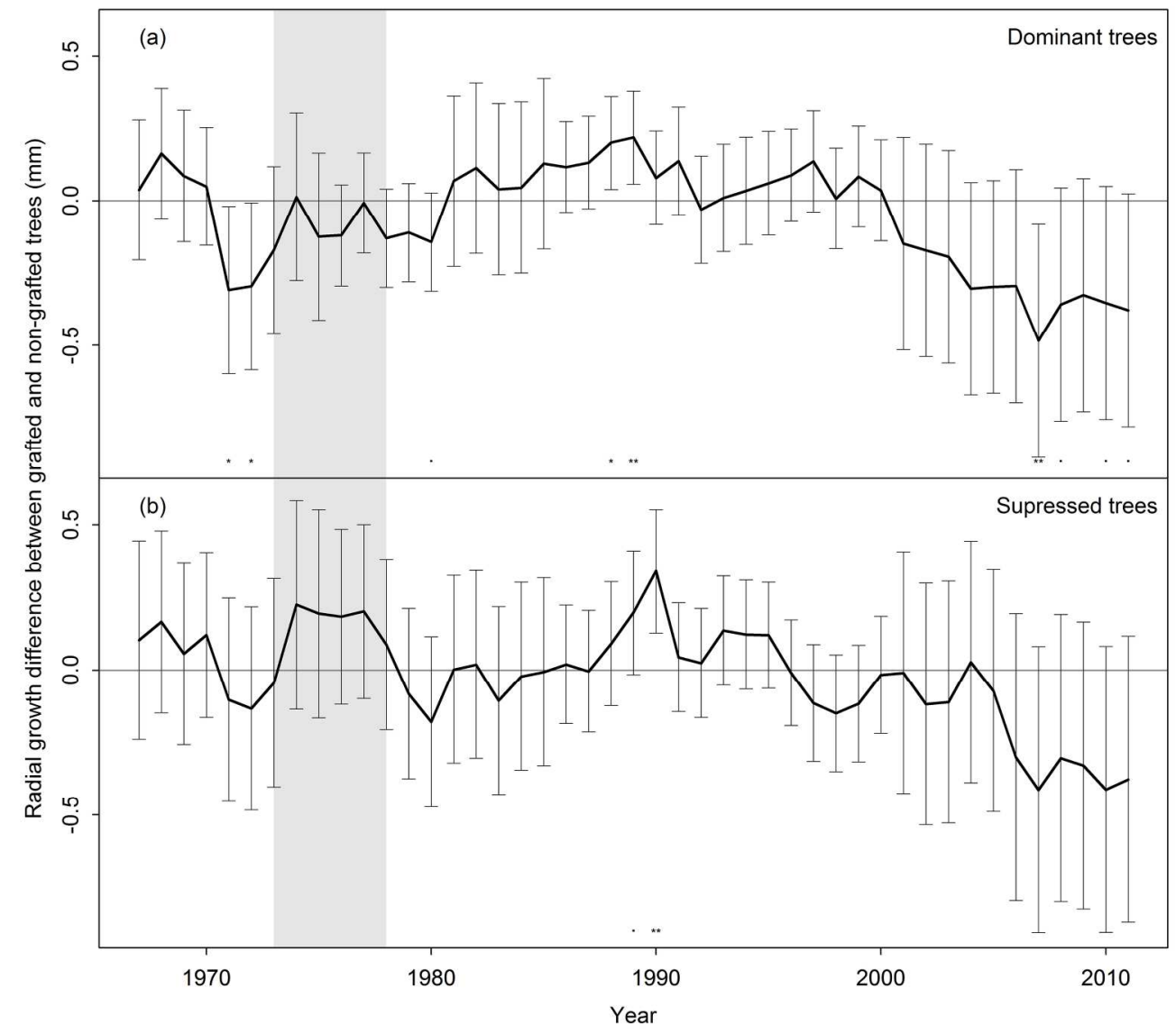

Differences in yearly radial growth between grafted and non-grafted trees among dominant (a) and suppressed (b) status. $199 \times 177 \mathrm{~mm}(300 \times 300 \mathrm{DPI})$ 
Table S1. Mixed models adjusted to compare radial growth between dominant and suppressed spruce trees during the surveyed period (YEAR_STATUS model). The temporal series are split into shorter temporal sets of five years in most cases. Degrees of freedom, $F$-values and $p$-values are shown.

\begin{tabular}{|c|c|c|c|c|}
\hline Temporal set & factor & DF & $F$ value & $p$ value \\
\hline \multirow{4}{*}{$1967-1970$} & Intercept & 1 & 22.0103 & $<.0001^{* * *}$ \\
\hline & Year & 3 & 16.7772 & $<.0001^{* * *}$ \\
\hline & Status & 1 & 0.0001 & 0.9948 \\
\hline & Year:Status & 3 & 2.3565 & $0.0713^{\circ}$ \\
\hline \multirow{4}{*}{ 1971-1975 } & Intercept & 1 & 12.6344 & $0.0004^{\text {*** }}$ \\
\hline & Year & 4 & 31.5177 & $<.0001^{* * *}$ \\
\hline & Status & 1 & 0.0713 & 0.7911 \\
\hline & Year:Status & 4 & 1.1365 & 0.3383 \\
\hline \multirow{4}{*}{ 1976-1980 } & Intercept & 1 & 45.3801 & $<.0001^{* * * *}$ \\
\hline & Year & 4 & 56.0558 & $<.0001^{* * *}$ \\
\hline & Status & 1 & 0.0048 & 0.9454 \\
\hline & Year:Status & 4 & 1.1584 & 0.3283 \\
\hline \multirow{4}{*}{$1981-1985$} & Intercept & 1 & 26.3934 & $<.0001^{* * *}$ \\
\hline & Year & 4 & 45.3401 & $<.0001^{* * *}$ \\
\hline & Status & 1 & 0.0316 & 0.8601 \\
\hline & Year:Status & 4 & 2.3180 & $0.0560^{\circ}$ \\
\hline \multirow{4}{*}{$1986-1990$} & Intercept & 1 & 21.2795 & $<.0001^{* * *}$ \\
\hline & Year & 4 & 41.6464 & $<.0001^{* * *}$ \\
\hline & Status & 1 & 2.9883 & $0.0932^{\circ}$ \\
\hline & Year:Status & 4 & 4.4513 & $0.0015^{* *}$ \\
\hline \multirow{4}{*}{ 1991-1995 } & Intercept & 1 & 100.0804 & $<.0001^{* * *}$ \\
\hline & Year & 4 & 29.5442 & $<.0001^{* * *}$ \\
\hline & Status & 1 & 8.1721 & $0.0073^{* *}$ \\
\hline & Year:Status & 4 & 4.9176 & $0.0007^{* * *}$ \\
\hline \multirow{4}{*}{$1996-2000$} & Intercept & 1 & 157.6464 & $<.0001^{* * *}$ \\
\hline & Year & 4 & 14.0907 & $<.0001^{* * *}$ \\
\hline & Status & 1 & 8.8337 & $0.0055^{* *}$ \\
\hline & Year:Status & 4 & 5.5215 & $0.0002^{* * *}$ \\
\hline \multirow{4}{*}{ 2001-2005 } & Intercept & 1 & 83.0460 & $<.0001^{* * *}$ \\
\hline & Year & 4 & 13.5925 & $<.0001^{* * *}$ \\
\hline & Status & 1 & 8.9059 & $0.0053^{* *}$ \\
\hline & Year:Status & 4 & 2.8984 & $0.0215^{*}$ \\
\hline \multirow{4}{*}{ 2006-2011 } & Intercept & 1 & 70.5199 & $<.0001^{* * *}$ \\
\hline & Year & 5 & 12.2587 & $<.0001^{* * *}$ \\
\hline & Status & 1 & 3.3196 & $0.0775^{\circ}$ \\
\hline & Year:Status & 5 & 0.5575 & 0.7326 \\
\hline
\end{tabular}

$* * *<0.001 ; * *<0.01 ; *<0.05 ; \bullet<0.1 ;$ significance codes 
Table S2. Mixed models adjusted to compare radial growth between grafted and non-grafted spruce trees during the surveyed period. The temporal series are split into shorter temporal sets of five years in most cases. Dominant and suppressed trees are separately analyzed (models YEAR_DOM and YEAR_SUP, respectively). Degrees of freedom, $F$-values and $p$ values are shown.

\begin{tabular}{|c|c|c|c|c|c|c|c|}
\hline \multirow{2}{*}{ Temporal set } & \multirow{2}{*}{ factor } & \multicolumn{3}{|c|}{ YEAR_DOM } & \multicolumn{3}{|c|}{ YEAR_SUP } \\
\hline & & $\overline{D F}$ & $F$ value & $p$ value & $\overline{D F}$ & $F$ value & $p$ value \\
\hline \multirow{4}{*}{$1967-1970$} & Intercept & 1 & 52.3336 & $<.0001^{* * *}$ & 1 & 12.2872 & $0.0006^{* * *}$ \\
\hline & Year & 3 & 16.8081 & $<.0001^{* * *}$ & 3 & 6.6512 & $0.0003^{* * *}$ \\
\hline & Graft & 1 & 0.5796 & 0.4473 & 1 & 0.7893 & 0.3754 \\
\hline & Year:Graft & 3 & 0.4651 & 0.7069 & 3 & 0.2395 & 0.8687 \\
\hline \multirow{4}{*}{$1971-1975$} & Intercept & 1 & 31.9149 & $<.0001^{* * *}$ & 1 & 6.1933 & $0.0134^{*}$ \\
\hline & Year & 4 & 28.2721 & $<.0001^{* * *}$ & 4 & 10.1261 & $<.0001^{* * *}$ \\
\hline & Graft & 1 & 1.8453 & 0.1944 & 1 & 0.2736 & 0.6013 \\
\hline & Year:Graft & 4 & 4.0708 & $0.0032^{* *}$ & 4 & 2.9126 & $0.0220^{*}$ \\
\hline \multirow{4}{*}{$1976-1980$} & Intercept & 1 & 126.5245 & $<.0001^{* * *}$ & 1 & 25.1267 & $<.0001^{* * *}$ \\
\hline & Year & 4 & 44.1246 & $<.0001^{* * *}$ & 4 & 22.4472 & $<.0001^{* * *}$ \\
\hline & Graft & 1 & 1.3279 & 0.2502 & 1 & 0.2025 & 0.6530 \\
\hline & Year:Graft & 4 & 1.4950 & 0.2039 & 4 & 2.4196 & $0.0489^{*}$ \\
\hline \multirow{4}{*}{ 1981-1985 } & Intercept & 1 & 18.4289 & $<.0001^{* * *}$ & 1 & 42.0024 & $<.0001^{* * *}$ \\
\hline & Year & 4 & 38.8026 & $<.0001^{* * *}$ & 4 & 14.6786 & $<.0001^{* * *}$ \\
\hline & Graft & 1 & 0.3828 & 0.5454 & 1 & 0.4777 & 0.4901 \\
\hline & Year:Graft & 4 & 1.2313 & 0.2978 & 4 & 0.9625 & 0.4285 \\
\hline \multirow{4}{*}{ 1986-1990 } & Intercept & 1 & 13.2479 & $0.0003^{* * *}$ & 1 & 40.3528 & $<.0001^{* * *}$ \\
\hline & Year & 4 & 23.2986 & $<.0001^{* * *}$ & 4 & 23.7471 & $<.0001^{* * *}$ \\
\hline & Graft & 1 & 2.4437 & 0.1191 & 1 & 0.7661 & 0.3822 \\
\hline & Year:Graft & 4 & 2.2259 & $0.0665^{\circ}$ & 4 & 2.5686 & $0.0385^{*}$ \\
\hline \multirow{4}{*}{ 1991-1995 } & Intercept & 1 & 33.8666 & $<.0001^{* * *}$ & 1 & 56.1074 & $<.0001^{* * *}$ \\
\hline & Year & 4 & 25.4243 & $<.0001^{* * *}$ & 4 & 10.8194 & $<.0001^{* * *}$ \\
\hline & Graft & 1 & 0.0641 & 0.8004 & 1 & 1.5731 & 0.2109 \\
\hline & Year:Graft & 4 & 3.3192 & $0.0112^{*}$ & 4 & 1.4132 & 0.2298 \\
\hline \multirow{4}{*}{ 1996-2000 } & Intercept & 1 & 115.0536 & $<.0001^{* * *}$ & 1 & 31.2477 & $<.0001^{* * *}$ \\
\hline & Year & 4 & 19.4813 & $<.0001^{* * *}$ & 4 & 3.0596 & $0.0173^{*}$ \\
\hline & Graft & 1 & 0.0026 & 0.9593 & 1 & 0.2393 & 0.6251 \\
\hline & Year:Graft & 4 & 2.7110 & $0.0305^{*}$ & 4 & 1.8025 & 0.1286 \\
\hline \multirow{4}{*}{$2001-2005$} & Intercept & 1 & 131.8272 & $<.0001^{* * *}$ & 1 & 8.9777 & $0.0030^{* *}$ \\
\hline & Year & 4 & 11.4829 & $<.0001^{* * *}$ & 4 & 4.9484 & $0.0007^{* * *}$ \\
\hline & Graft & 1 & 1.6017 & 0.2250 & 1 & 0.0679 & 0.7980 \\
\hline & Year:Graft & 4 & 1.3878 & 0.2383 & 4 & 3.0528 & $0.0175^{*}$ \\
\hline \multirow{4}{*}{ 2006-2011 } & Intercept & 1 & 84.2626 & $<.0001^{* * *}$ & 1 & 6.1188 & $0.0139^{*}$ \\
\hline & Year & 5 & 10.5890 & $<.0001^{* * *}$ & 5 & 3.9363 & $0.0018^{* *}$ \\
\hline & Graft & 1 & 3.1424 & $0.0966^{\circ}$ & 1 & 1.9678 & 0.1810 \\
\hline & Year:Graft & 5 & 3.9063 & $0.0019^{* *}$ & 5 & 2.1770 & $0.0564^{\circ}$ \\
\hline
\end{tabular}

$* * *<0.001 ; * *<0.01 ; *<0.05 ; \bullet<0.1 ;$ significance codes 